\title{
The geological framework for Hvideklint, south-east Denmark, using glaciodynamic sequence stratigraphy
}

\author{
Stig A. Schack Pedersen* (D), Peter Gravesen \\ Geological Survey of Denmark and Greenland (GEUS), Copenhagen, Denmark
}

\begin{abstract}
Glaciodynamic sequence stratigraphy provides a practical model for grouping and classifying complex geological data to aid interpretation of past climatic and environmental development in Quaternary successions. The principles of glaciodynamic sequence stratigraphy are applied here to summarise the complex glacial geological framework of Hvideklint on the island of Møn, south-east Denmark. The framework of the superimposed deformed Hvideklint is presented in a reconstructed geological cross-section of Hvideklint. For the construction of the architecture of the glaciotectonic complex, the interpretation of structures below sea level was based on a detailed new survey of the cliff section combined with construction of successive approximation balanced cross-sections. The new description is supported by drill hole data from the Jupiter database. Where chalk is not glaciotectonically deformed, the constructed depth to the top-chalk-surface is generally located about $30 \mathrm{~m}$ below sea level. In Hvideklint, thrust sheets with chalk are exposed $20 \mathrm{~m}$ above sea level, and the balanced cross-section constructions indicate that the décollement surface for a Hvideklint glaciotectonic complex is located about $80 \mathrm{~m}$ below sea level. Between the décollement level and the top of the complex, two or more thrust-fault flat-levels and connecting ramps add to the complex architecture of Hvideklint.
\end{abstract}

\section{Introduction}

The Danish land surface is comprised of a complex sequence of deformed glacial deposits. The principles of glaciodynamic sequence stratigraphy provide a practical model for grouping and classifying such complex geological data to aid interpretation of past climatic and environmental development in Quaternary successions. Furthermore, the concept of glaciodynamic sequence stratigraphy presents a system for predicting the successions expected in drill holes or excavations during constructive works.

Here, we apply the principles of glaciodynamic sequence stratigraphy to summarise the complex glacial geological framework of Hvideklint on the island of Møn, south-east Denmark (Fig. 1) and present a new geological cross-section of Hvideklint (Fig. 2). This work is part of a larger project at the Geological Survey of Denmark and Greenland (GEUS) to

\author{
*Correspondence: sasp@geus.dk \\ Received: 12 Mar 2019 \\ Accepted: 2 Nov 2021 \\ Published: 14 Dec 2021 \\ Keywords: Glaciotectonics, \\ Glacioldynamics, Sequence stratigraphy, \\ Lower Maastrichtian chalk
}

\begin{abstract}
Abbreviations:
GEUS: Geological Survey of Denmark and Greenland

HK: Hvideklint

GEUS Bulletin is an open access, peerreviewed journal published by the Geological Survey of Denmark and Greenland (GEUS). This article is distributed under a CC-BY 4.0 licence, permitting free redistribution, and reproduction for any purpose, even commercial, provided proper citation of the original work. Author(s) retain copyright.
\end{abstract}

Edited by: Catherine N Jex (GEUS, Denmark)

Reviewed by: Daniel Paul Le Heron (University of Vienna, Austria) and one anonymous reviewer

Funding: See page 7

Competing interests: None declared

Additional files: None provided 


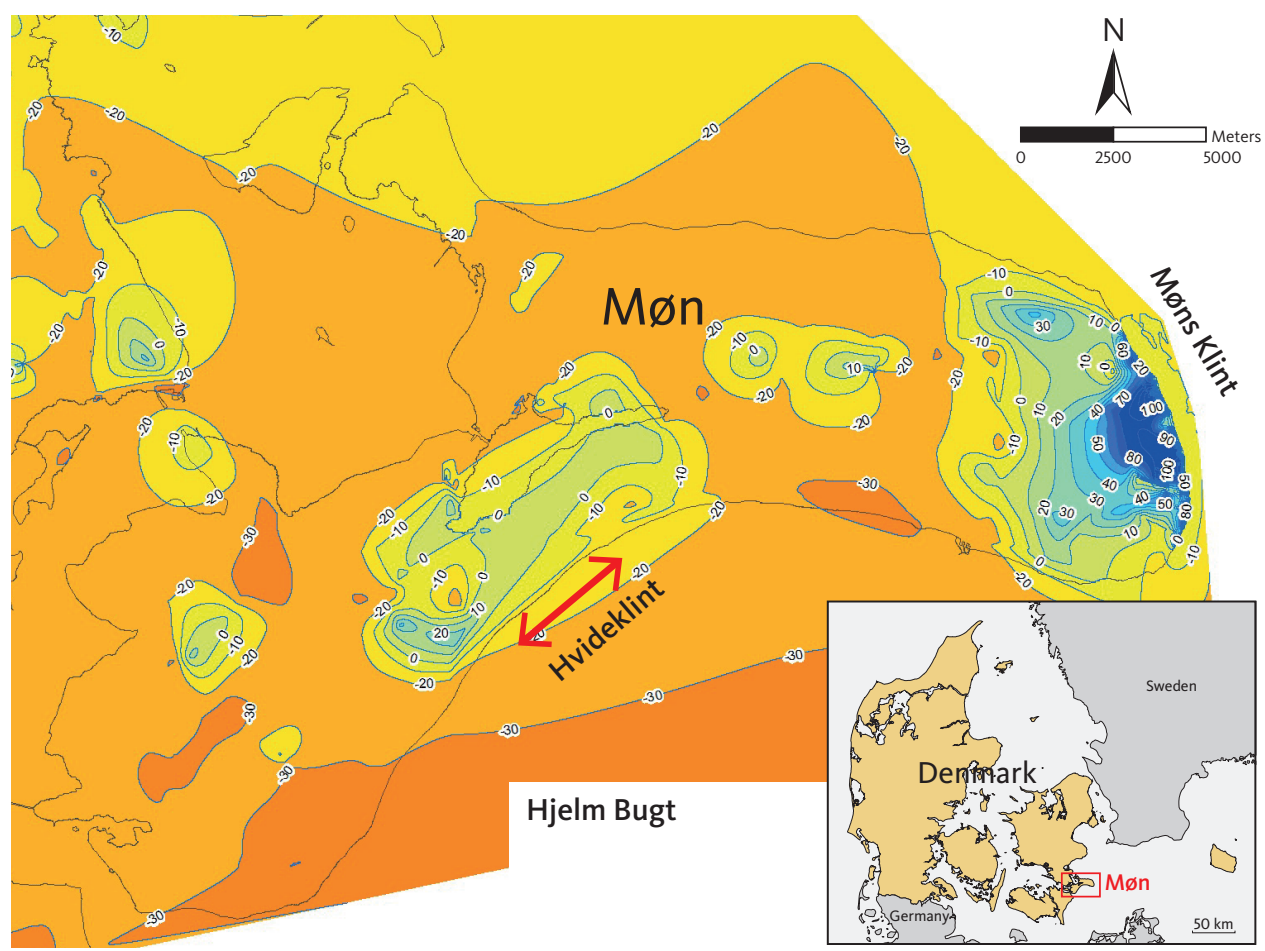

Fig. 1 Location of Hvideklint, Møn, south-east Denmark. The position of the cross-section (Fig. 2) is marked by a red arrow. Contour intervals mark the depth of the pre-Quaternary surface (the top of the Cretaceous chalk). The construction of contours is based on an ArcGIS algorithm applied to the well data from Møn (Jupiter database, GEUS). The top-chalk surface occurs mainly at $20-30 \mathrm{~m}$ b.s.l. The exception of this is the areas where it is elevated above sea level in the glaciotectonic complexes. The contour map is simplified from Pedersen \& Gravesen (2021).
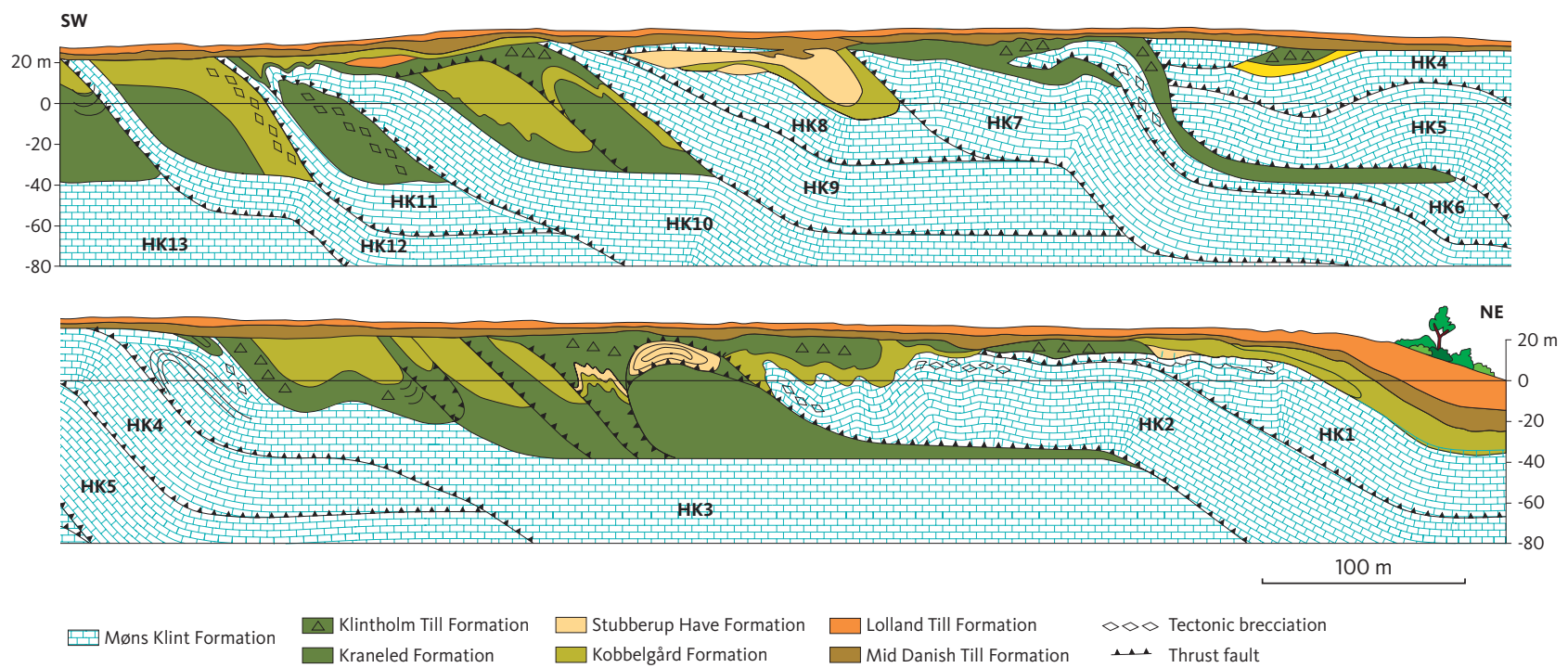

Fig. 2 New geological cross-section of Hvideklint (HK). The interpretation of structures below sea level is based on successive balanced cross-section constructions according to the concept described by Pedersen (2005). Chalk thrust sheets are annotated HK1 to HK13 from NE to SW. Slightly modified from Pedersen \& Gravesen (2021).

produce a systematic geological description of the island (Pedersen \& Gravesen 2021).

The basic challenge in stratigraphy is to correlate successions from one observation point to another. Some boundaries can be traced as lithological surfaces, from which we construct a layer-cake model of stratigraphy across a region. However, complex successions containing superimposed deformation structures or erosional irregularities may require a different approach. Here, a dynamic model is required to construct a geological framework and explain the relationship between interpreted deposits and their boundaries.

Sequence stratigraphy is an established model for describing complex sedimentary systems. It explains the stacking patterns and origins of sedimentary successions driven by changing sea levels. During ice ages, sea-level change is predominantly controlled by the accumulation of ice in terrestrial ice sheets. 
Glaciodynamic sequence stratigraphy establishes a model for glacial sediments and their relationship to glacial tectonics (Pedersen 2012).

As an ice sheet builds up, a sequence of glaciofluvial sediments is deposited in the proglacial area, in front of the ice margin. The deposition of these sediments ended by the transgression of the ice sheet and deposition of a lodgement till along the base of the ice. The deposits below the till will be affected by glaciotectonic processes, primarily as a proglacial thrust and fold complex and secondly by creating an unconformity between the glaciotectonic complex and a subglacially deposited basal till. The glaciotectonic unconformity truncates the thrust and fold structures, above which a glacitectonite may develop by shearing along the base of the ice in the so-called deformational layer (Pedersen 2012).

\section{Methods}

A detailed new survey of the cliff section was carried out in 2015-2016. Combined with construction of successive approximation-balanced cross-sections, we constructed the architecture of the glaciotectonic complex and interpretated the structures below sea level. The new description of Hvideklint is supported by previous descriptions of the cliff section (Aber 1979 and an unpublished master thesis by Tove Krogh Stockmarr 1996, see acknowledgement). It is further supported by drill hole data from the GEUS Jupiter database and the constructed depth to the top-chalk-surface formerly presented in the cross-section E-F in the Geological Map 1:50 000 of Møn (Pedersen \& Gravesen 2006, 2021). We refer the reader to Pedersen \& Gravesen (2021) for a description of methods.

\section{Hvideklint geological description}

Hvideklint is a more than $1 \mathrm{~km}$ long, $20 \mathrm{~m}$ high coastal cliff, facing the western part of Hjelm Bugt on the island of Møn, south-east Denmark (Fig. 1). The cross-section along the costal cliff strikes NE-SW (Fig. 2), almost perpendicular to the main direction of the strike of thrust faults and direction of the fold axes (Fig. 3). The cliff comprises more than 13 thrust sheets of upper Cretaceous chalk overlain by Quaternary glacial deposits. Displacement of the glaciotectonic thrust sheets occurred in the later part of the Weichselian glaciation (Aber 1979). Saalian, Eemian and the oldest Weichselian deposits are displaced along the cliff. The youngest Weichselian deposits discordantly truncate the thrust fault complex.

The geological framework of Hvideklint consists of three main elements: (1) Cretaceous chalk sits beneath a brecciated unconformity, overlain mainly by glaciolacustrine sediments, thrust up by the proglacial push
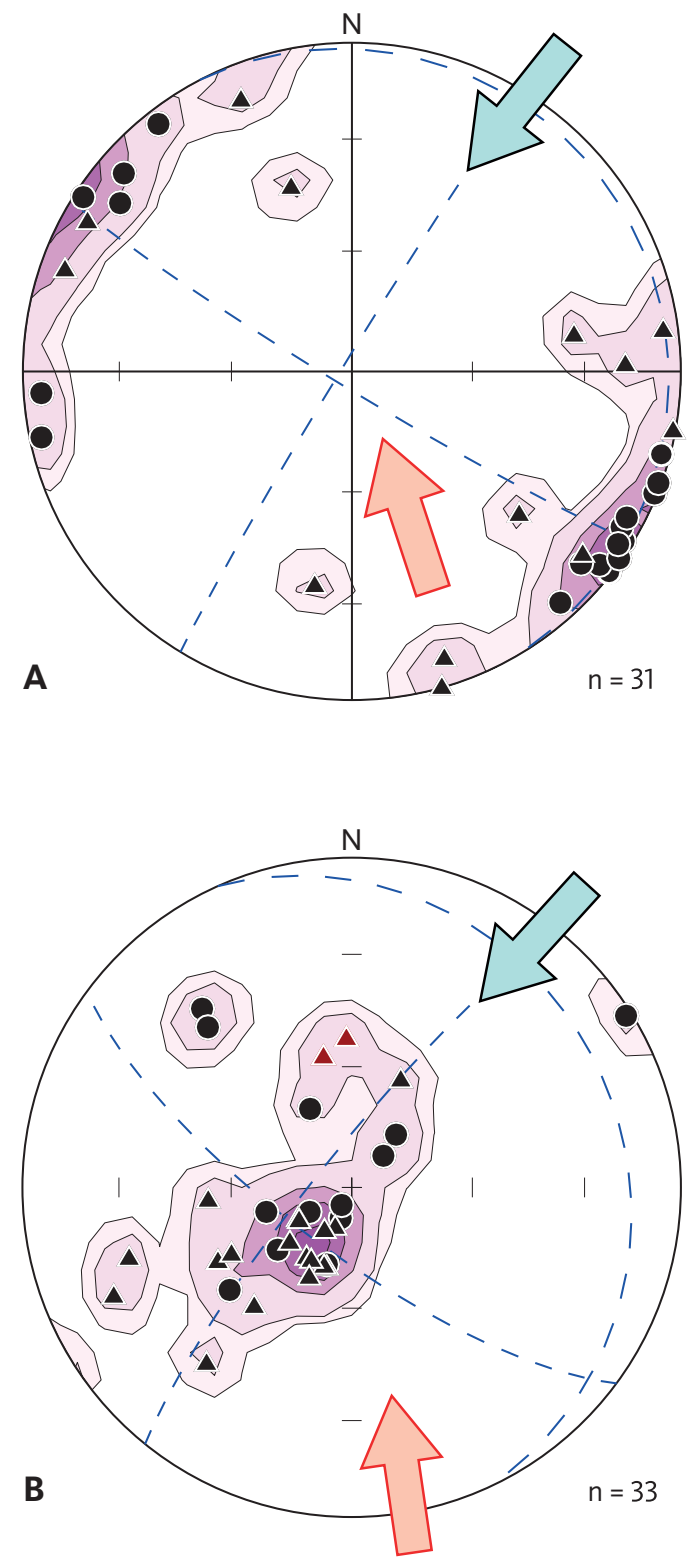

Fig. 3 Stereogrammetric projections of structural orientations measured along the Hvideklint section. Stereograms are lower hemisphere, equal area (Schmidt) net projections. Contour intervals are semistatistic densities 1, 5, 10 and 15\%. Blue dotted lines indicate principal directions of stress/strain. A: Fold axes orientations. Black dots are fold axes representing the deformation from the north-east (the Hvideklint glaciodynamic event, ice advance indicated by blue arrow). Black triangles indicate second phase of deformation from the south (Møns Klint glaciodynamic event indicated by red arrow) and/or superimposed deformed fold axes. B: Bedding planes (black dots) and thrust planes (black triangles) are plotted by their normal to the planes. Main orientation of planes shows a concentration of strike and dip around $135^{\circ} / 20^{\circ} \mathrm{NE}$. Red triangles represent thrusting from the south. The two arrows represent similar glaciodynamic impacts as in A.

of the Swedish Ice Advance from the north-east; (2) the superimposition of the glaciotectonic complex by the northward push of the Baltic Ice Advance and (3) heavily 
brecciated chalk-clay sediments and formation of mud diapirism (Stockmarr 1996).

\subsection{Lithostratigraphy}

The lithologies present at Hvideklint are summarised in Figs 2 and 4 and described below.

\subsubsection{Cretaceous chalk}

The Cretaceous chalk is a white, grey-white or slightly yellowish coccolith chalk. Black chert (flint) nodules are common (Fig. 5), but continuous bands of chert are absent. In some places, chalk and marl lithologies occur with conglomeratic features (Fig. 6). These lithologies correlate to the uppermost Campanian - lowermost Maastrichtian (c. $72 \mathrm{Ma}$ ), the transition from the Boesdal Member in the Mandehoved Formation to the Hvidskud Member in the lowermost part of the Møns Klint Formation (Thomsen 1995; Surlyk et al. 2013).

\subsubsection{Quaternary deposits}

The oldest Quaternary deposit at Hvideklint is interglacial, marine clay of Eemian age resting on Saalian glacial deposits (Fig. 6). Mollusc fauna of Eemian age occurs in the black to dark greyish clay in the lowest part of the
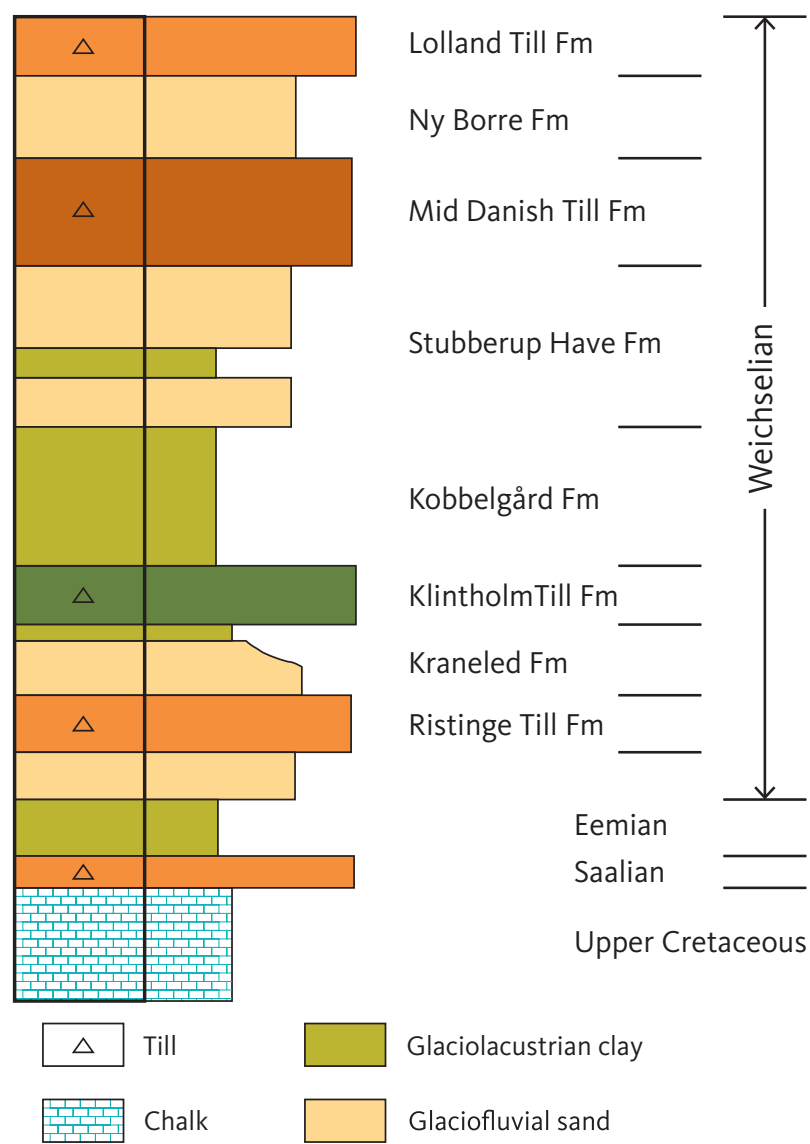

Fig. 4 Simplified geological succession at Hvideklint. Geological units as in Fig. 2.
Quaternary lithostratigraphy. However, the Eemian clay rests on an irregular unconformity above the chalk. The top of the chalk is often brecciated and forms a glacitectonite, and residual gravel preserved in pockets along the unconformity indicates the remnants of glacial deposits and glaciotectonics related to the glacial dynamics prior to Eemian, here interpreted as Saalian.

The oldest till bed is the Ristinge Till Formation (Houmark-Nielsen 1987), a red-brown diamictite deposited during ice advance across the Baltic in the Early-Middle Weichselian, often referred to as the Old Baltic Ice. The reddish colour is generally interpreted as the

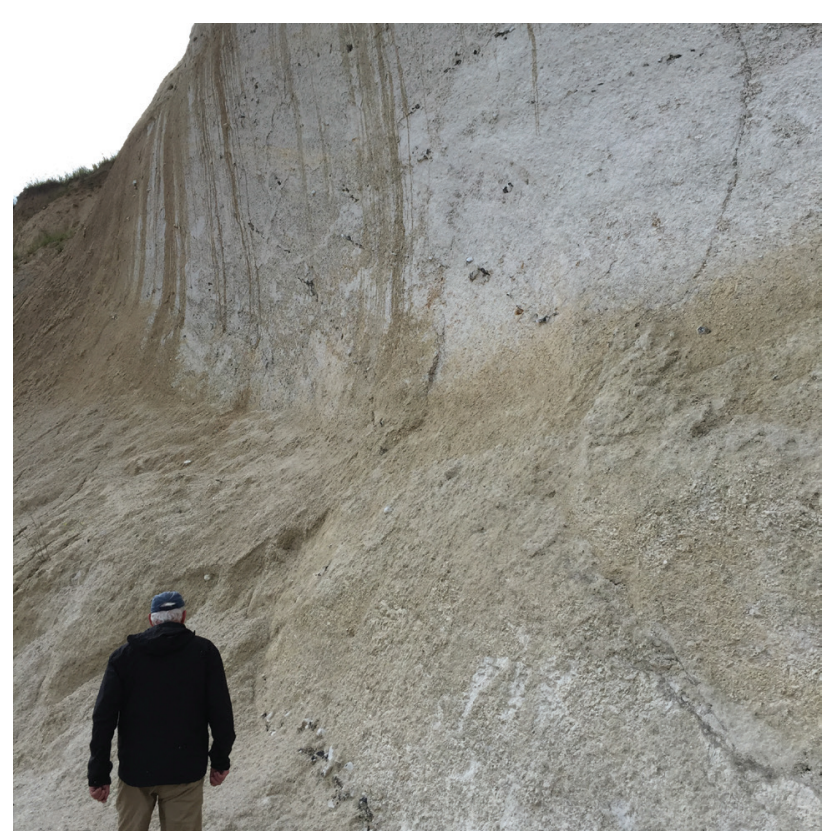

Fig. 5 Upper Cretaceous chalk at Hvideklint. Note the occurrence of nodular flint in the chalk.

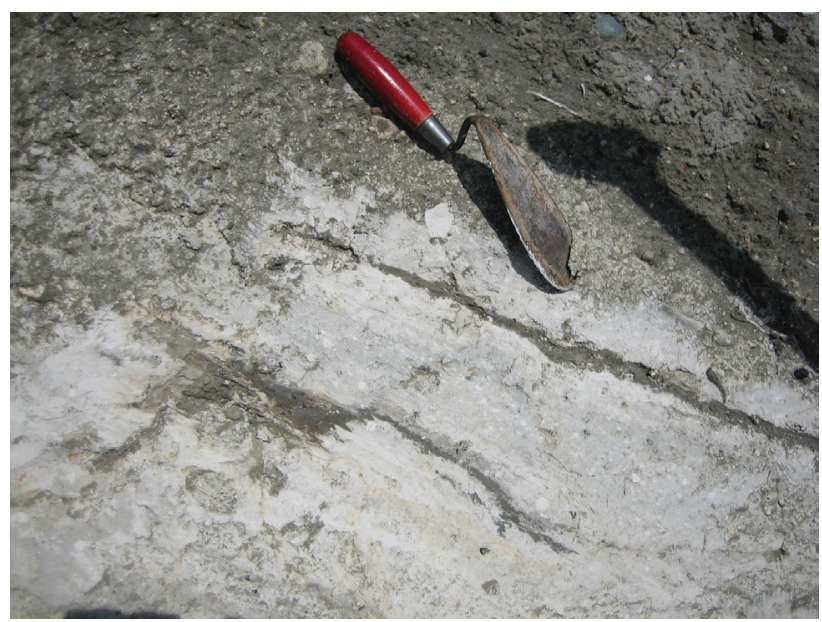

Fig. 6 Brecciated chalk interpreted here as a mixture of conglomeratic chalk and marl at the boundary between Campanian and Maastrichtian chalk. The shear structures indicate superimposed deformation by shearing along the thrust fault at the base of the chalk. The unit is classified as a chalk-tectonite. 
debris plugged up during the ice advance over the preCambrian Nexø sandstone and similar lithologies in the eastern Baltic. The Ristinge Till Formation is overlain by a heterolithic unit of glaciofluvial and glaciolacustrine sediments named the Kraneled Formation (Fig. 4), which is capped by the dark grey coloured Klintholm Till Formation (Houmark-Nielsen 1994, 2010; Pedersen \& Gravesen 2021). These units are mainly shear-mixed and difficult to differentiate in detail. The Klintholm Till Formation was previously dated to the Middle Weichselian, c. 34-30 ka BP (Houmark-Nielsen 2010; HoumarkNielsen et al. 2016).

Above the Klintholm Till Formation is a clay-dominated unit of glacial deposits, referred to as the Kobbelgård Formation (Pedersen \& Gravesen 2021; Fig. 4). This unit is thought to have formed in a large lake covering the Baltic depression during the interstadial period prior to the Late Glacial Maximum in the last part of the Weichselian (Pedersen \& Gravesen 2009). In the top of the Kobbelgård Formation, deposits of glaciofluvial sand are intercalated in the clay. At the NE part of Møn, the glaciofluvial sand unit is defined as the Stubberup Have Formation (Fig. 6; Pedersen \& Gravesen 2021). Below the thrust zones, sandy lithologies are almost absent at Møns Klint, where the clay in the Kobbelgård Formation (formerly named elephant clay) typically occurs below the base of the chalk thrust sheets.

The Mid Danish Till Formation, which truncates the tips of the thrust sheet, is a grey-brownish, basal till, representing the Last Glacial Maximum during the final stadial in the Weichselian (Houmark-Nielsen 1987). It was deposited during the advance of the Swedish Ice Stream shortly after the Hvideklint glaciotectonic complex formed in the proglacial area.

The glacial succession at Hvideklint is capped by an orange-yellow-brown till. Below the base of this till, the Ny Borre Formation is located in other parts of Møn (Pedersen \& Gravesen 2021), but at Hvideklint, it is only represented by an unconformity between Mid Danish Till and the top till. The latter is the Lolland Till Formation, deposited by the Young Baltic Ice Advance about 18 ka BP (Pedersen et al. 2015). The Young Baltic Ice advanced northwards from Baltic, where it terminated at its stationary line in the central part of Kattegat (Pedersen \& Petersen 1997). The interval between the Mid Danish Till Formation and the Lolland Till Formation is separated by a thin, irregular unit of sand and gravel, indicating that the Swedish Ice Stream had melted back before the Young Baltic Ice transgressed the area.

\subsection{Structural geology}

The Hvideklint cross-section comprises more than 13 thrust sheets of chalk, piggybacked by a unit of glacial deposits (HK1-13, Fig. 2; HK: Hvideklint). Based on an ArcGIS construction of the well data from Møn (Jupiter database, GEUS), the surface of the top of the chalk (pre-Quaternary unconformity) occurs mainly at 20-30 m b.s.l., except where it is elevated above sea level in the glaciotectonic complexes (Fig. 1). After drafting the cross-section of the coastal cliff section at Hvideklint, balanced cross-sections were constructed following the principles of line-balance and displacement off-set. The base level for the displaced chalk thrust-sheets, defined as the décollement surface, was subsequently located 70-80 $\mathrm{m}$ b.s.l. The construction of the structures below sea level is a central new contribution, which is not integrated in the cross-section provided by Aber (1979).

The thrust sheets are annotated HK1-HK13 from NE to the SW in Fig. 2. The outcrop of the westernmost thrust sheet (HK13) and thrust sheets west of this are at present obscured by screes (west of the cross-section depicted in Fig. 2), mirroring the dominance of clayey units in the coast cliff.

Stereogrammetric plots of structural orientations measured along the Hvideklint section are shown in Fig. 3. In general, the thrust faults strike SE-NW (c. 135') and the dips of thrust fault ramps vary from $45^{\circ} \mathrm{NE}$ at the base of the cliff, becoming westerly (bending towards sub-horizontal) at the top of the cliff section (Fig. 3). The thrust fault complex dominated by the glaciotectonic deformation from the north-east is superimposed by deformation from the south. This is best illustrated by the double-fold on the back of thrust sheet HK3, just in front of the tip of HK2 (Fig. 2). Here, the Kobbelgård Formation is tightly folded with inversion of the southern limb in a syncline fold with a southerly dipping axial plane (Fig. 7). This type of superimposed structural feature, combined with an oblique cut of the structures (cross-section cut is not perpendicular to the direction of fold axis), is responsible for most of the irregularities identified in the cliff section.

Shear deformation with stretching of chalk debris and thin chalk flows is another important disturbance in the complex (Fig. 8). A tectonic breccia formed the base of the thrust sheet, where the hanging-wall thrust sheet is displaced, and part of the décollement zone is thrust up along the ramp. Here, the tectonically brecciated chalk is regarded as a tectonite. Another type of tectonite formed along the base of the glacier ice, where the deformed layer sheared the top of the thrust sheets. The chalk breccias formed here are classed as chalk-glacitectonites (Pedersen 1988). In the ideal glaciodynamic succession, the glacitectonites should always occur beneath a basal till, indicating that the first phase of ice transgression involved strong shearing along the base of the ice, after which basal till accumulated. 

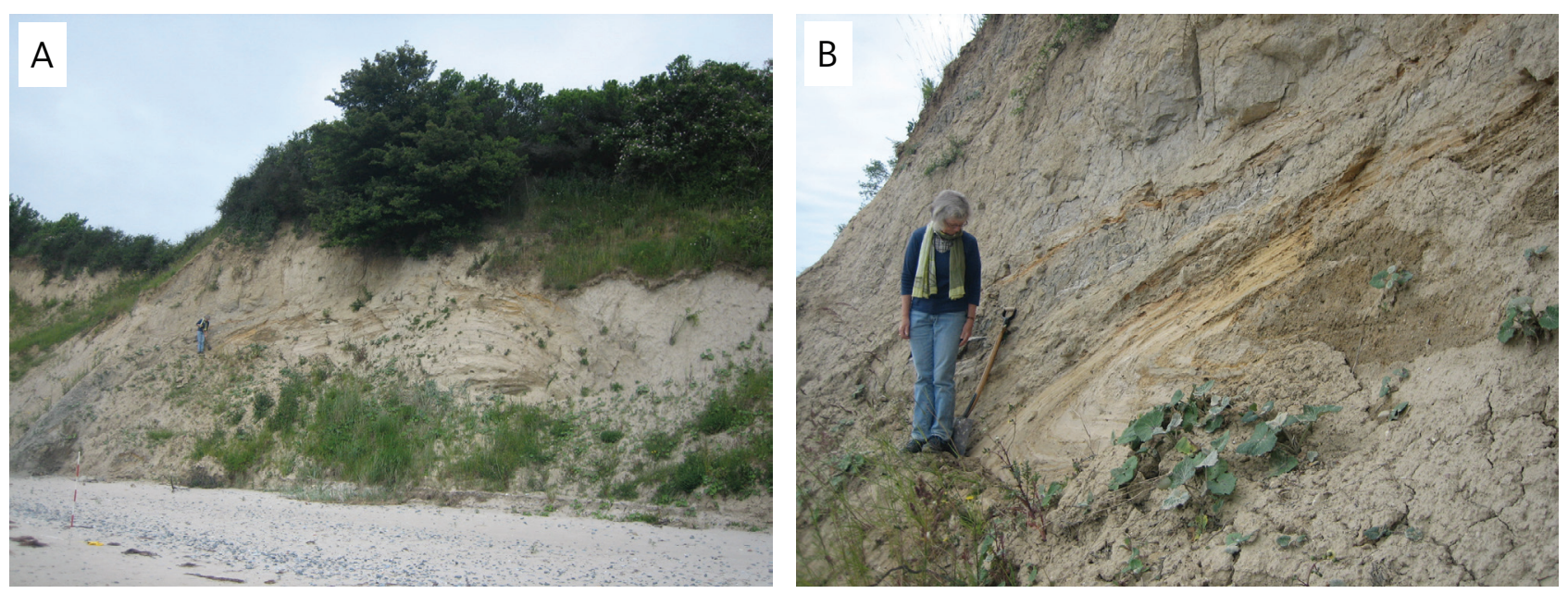

Fig. 7 Refolded beds of Hvideklint units. A: The position of the overturned syncline in the Hvideklint coastal cliff. B: Close-up of the overturned syncline with the heterolithic beds of the Kobbelgård and Stubberup Have formations.

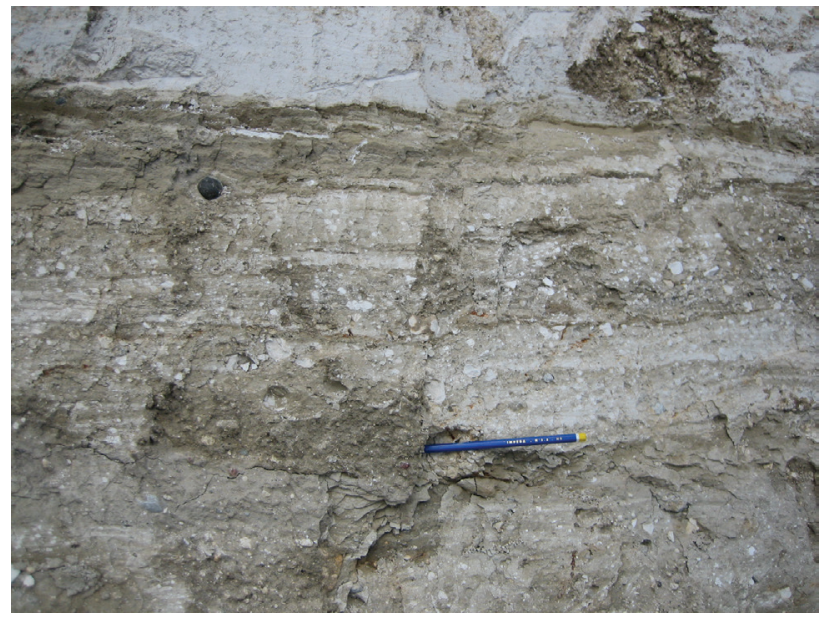

Fig. 8 Chalk-tectonite formed along the décollement zone below the displaced thrust sheet of HK4 (see Fig. 2). Note that a tectonite is the tectonic breccia below the displaced thrust sheet, in contrast to a glacitectonite, which is the tectonic breccia formed underneath the inferred former ice base.

\subsection{Glaciodynamic development}

A glaciodynamic sequence corresponds to a glaciodynamic event (Pedersen 2012). At the base of the sequence, a décollement zone develops during the formation of a tectonite. Dynamically, this develops simultaneously with the deposition of proglacial meltwater sand and clay (Fig. 9, phase A). The second phase in the glaciodynamic event displaces the thrust sheets comprising the pre-Quaternary units overlain by the proglacial deposits (Fig. 9, phase B). During the third phase, the thrust fault complex is transgressed by the ice, which truncates the top of the complex, establishing a glaciotectonic unconformity under the formation of a glacitectonite (Fig. 9, phase C). The basal till above the glacitectonite marks the end of the glaciodynamic

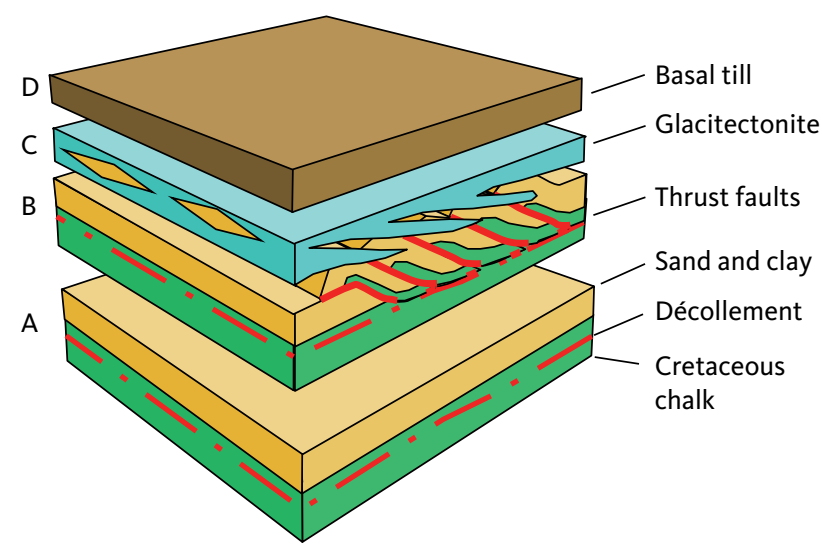

Fig. 9 The glaciodynamic sequence system as applied to Hvideklint. Phase A: The décollement zone consists of a tectonite at the base of the thrust sheets, which may include mobilised mud diapirs. Glacio-fluvial and Glacio-lacustrine units are deposited prior to proglacial deformation. Phase B: An allochthonous unit of pre-Quaternary and/or pre-glacial sedimentary deposits, bounded by thrust faults representing the second order surfaces in the glaciotectonic architecture. Phase C: A glaciotectonic unconformity including a glacitectonite is formed at the base of the advancing ice. Phase $\mathbf{D}$ : The glaciodynamic sequence is terminated by the deposition of the basal till. Slightly modified from Pedersen \& Gravesen (2021).

sequence (Fig. 9, phase D). Some sequences may only be partially represented, due to poorly preserved glacial deposits or underdeveloped glaciotectonic deformation (Fig. 9).

At Hvideklint, we have established four glaciodynamic events: (1) the Saalian glaciation, (2) the Klintholm glaciodynamic event, (3) the Hvideklint glaciodynamic event, and (4) the Møns Klint glaciodynamic event.

An early glaciodynamic event of Saalian (or older) age is represented by the glaciotectonic brecciations of the top of the chalk, upon which the Eemian clay was 
deposited. The main glaciodynamic sequence dominating Hvideklint relates to an event associated with the advance of the Swedish Ice Stream. We refer to this as the Hvideklint glaciodynamic event. However, the presence of two glaciotectonic displaced till units, the Ristinge Till Formation and the Klintholm Till Formation (Fig. 6), suggests that an earlier glaciodynamic event affected the area. The Old Baltic glaciodynamic event, referred to here as the Klintholm glaciodynamic event, is responsible for the deposition of these units, where the Baltic Ice Stream transgressed over a glaciolacustrine environment in the Hjelm Bugt - Baltic depression. The only glaciotectonic impact related to this event is the occurrence of a chalk-clay glacitectonite at the base of the till units (Fig. 6).

An interstadial period of about 10000 years (Houmark-Nielsen et al. 2016) between the Klintholm and Hvideklint glaciodynamic events allowed the large Baltic glacial lake to be re-established. At the Late Glacial Maximum, c. 32-25 ka BP, the advancing Swedish Ice Stream caused icebergs to deposit ice-rafted debris in the glaciolacustrine clay (Kobbelgård and Stubberup Have formations) and increased glaciofluvial streams provided sandy deposits, before the ice margin started to deform the Hvideklint glaciotectonic complex (Pedersen 2000; Pedersen \& Gravesen 2009, 2021).

After just a couple of thousand years, the Young Baltic glaciodynamic event affected the area. The most dramatic effect of this event was the glaciotectonic formation of Møns Klint itself, and we, therefore, refer to it as the Møns Klint glaciodynamic event. At Hvideklint, an ice lobe in Hjelm Bugt created the curved shape of the south coast of Møn. Due to the short-time span between the two glaciodynamic events, only a thin sequence of proglacial sediments was deposited on top of the Mid Danish till. However, the occurrence of chalk-rich glacitectonite evidently separates this till unit from the Lolland till unit, which terminates the glaciodynamic succession at Hvideklint.

\section{Conclusions}

Application of the glaciodynamic sequence stratigraphy allows a systematic reconstruction of the glaciotectonic events that deformed the glacial successions at Hvideklint. The two most recent events significantly added to the formation of Møn by the early glaciotectonic deformation of the cliffs and the hilly area of west Møn, and finally the formation of the hilly area of east Møn by the creation of the Møns Klint glaciotectonic complex. Superimposed folding results from the interference of the two events.

In this study, we place the top of the chalk (preQuaternary unconformity) to 20-30 m b.s.l. except for the areas, where it is elevated above sea level in the glaciotectonic complexes. The base level for the displaced chalk thrust-sheets is located at the décollement surface, 70-80 m b.s.l. At Hvideklint, the chalk is predominantly tectonically brecciated and forms a mixture of chalk-glacitectonite and chalk-rich till at the glaciotectonic unconformity truncating the top of the glaciotectonic complex.

\section{Acknowledgements}

Cand. Scient. Tove Krogh Stockmarr is thanked for permission to use parts of her master thesis on Hvideklint. Dr. Dan Le Heron and an anonymous referee provided helpful suggestions, which improved the text. Geodatalog Frantz v. Platen-Hallermund assisted with the ArcGIS construction of the top-chalk map (Fig. 1).

\section{Funding statement}

This study was stimulated and supported by the EU Horizon2020project 'SUBSOL' (grant agreement no. 642228, www.subsol.org).

\section{Competing interests}

None declared.

\section{Author contributions}

SSP: writing - original draft; SSP and PG: writing - review and editing, methodology and formal analysis.

\section{References}

Aber, J. 1979: Kineto-stratigraphy at Hvideklint, Møn, Denmark and its regional significance. Bulletin of the Geological Society of Denmark 28, 81-93.

Houmark-Nielsen, M. 1987: Pleistocene stratigraphy and glacial history of the central part of Denmark. Bulletin of the Geological Society of Denmark 36, 1-189. https://doi.org/10.37570/bgsd -1988-36-01

Houmark-Nielsen, M. 1994: Late Pleistocene stratigraphy, glaciation chronology and Middle Weichselian environmental history from Klintholm, Møn, Denmark. Bulletin of the Geological Society of Denmark 41, 181-202. https://doi.org/10.37570/bgsd-1995-41-16

Houmark-Nielsen, M. 2010: Extent, age and dynamics of Marine Isotope Stage 3 glaciation in the southwestern Baltic Basin. Boreas 39, 343-359. https://doi.org/10.1111/j.1502-3885.2009.00136.x

Houmark-Nielsen, M., Bennike, O., Lamdahl, G. \& Lüthgens, C. 2016: Evidence of ameliorated Middle Weichselian climate and sub-arctic environment in the western Baltic region: coring lake sediments at Klintholm, Møn, Denmark. Boreas 45, 347-359. https://doi. org/10.1111/bor.12159

Pedersen, S.A.S. 1988: Glacitectonite: brecciated sediments and cataclastic sedimentary rocks formed subglacially. In: Goldthwait, R.P. \& Matsch, C.L. (eds): Genetic classification of glacigenic deposits, 89-91. Rotterdam: A.A. Balkema.

Pedersen, S.A.S. 2000: Superimposed deformation in glaciotectonics. Bulletin of the Geological Society of Denmark 46, 125-144. https://doi. org/10.37570/bgsd-1999-46-11

Pedersen, S.A.S. 2005: Structural analysis of the Rubjerg Knude Glaciotectonic Complex, Vendsyssel, northern Denmark. Geological Survey of Denmark and Greenland Bulletin 8, 192 pp. + 2 plates. https://doi. org/10.34194/geusb.v8.5253

Pedersen, S.A.S. 2012: Glaciodynamic sequence stratigraphy. In: Huuse, M. et al. (eds.): Glaciogenic reservoirs and hydrocarbon systems $\mathbf{3 6 8}$ 29-51. London: Geological Society, Special Publications. https://doi. org/10.1144/sp368.2

Pedersen, S.A.S., Fredericia, J. \& Rasmussen, L.A. 2015: Kortbladsbeskrivelse, Geologisk kort over Danmark, 1:50 000, Sakskøbing 1411 
| og 1412 || Syd. Geological Survey of Denmark and Greenland Map Series 6, 42 pp. + kort.

Pedersen, S.A.S. \& Gravesen, P. 2006: Geologisk kort over Danmark 1:50 000, Møn. Geological map. Copenhagen: Geological Survey of Denmark and Greenland.

Pedersen, S.A.S. \& Gravesen, P. 2009: Structural development of Maglevandsfald: a key to understanding the glaciotectonic architecture of Møns Klint, SE Denmark. Geological Survey of Denmark and Greenland Bulletin 17, 29-32. https://doi.org/10.34194/geusb.v17.5007

Pedersen, S.A.S. \& Gravesen, P. 2021: Kortbladsbeskrivelse, Geologisk kort over Danmark, 1:50 000, Møn Dele af 1511 I, 1511 IV og 1512 II. GEUS Bulletin 48. 8293. (In Danish with an English summary). https:// doi.org/10.34194/geusb.v48.8293
Pedersen, S.A.S. \& Petersen, K.S. 1997: Djurslands Geologi, 96 pp. København: Danmarks og Grønlands Geologiske Undersøgelse.

Stockmarr, T.K. 1996: En kvartærgeologisk model over det sydvestlige Møn, 164 pp. Unpublished MSc thesis, University of Copenhagen, Denmark. (In Danish)

Surlyk, F., Rasmussen, S.L., Boussaha, M., Schiøler, P., Schovsbo, N.H., Sheldon, E., Stemmerik, L. \& Thibault, N. 2013: Upper Campanian-Maastrichtian holostratigraphy of the eastern Danish Basin. Cretaceous Research 46, 232-256. https://doi.org/10.1016/j. cretres.2013.08.006

Thomsen, E. 1995: Kalk og kridt i den danske underground. In: Nielsen, O.B. (red.): Danmarks geologi fra kridt til i dag, 31-67. Aarhus: Aarhus University. (In Danish). 